\title{
The proportion of hybrids in seed from a seed orchard composed of two larch species ( $L$ europaea and $L$ leptolepis)
}

\author{
M Häcker, F Bergmann
}

\begin{abstract}
Abteilung für Forstgenetik und Forstpflanzenzüchtung, Georg-August-Universität, D-3400 Göttingen, Germany
\end{abstract}

(Received 21 January 1991; accepted 17 June 1991)

\begin{abstract}
Summary - The proportion of hybrids in the seed produced in an orchard containing one European larch (Larix europaea) clone used as maternal tree and 271 Japanese larch (Larix leptolepis) clones used as pollinators was determined by isoenzymatic methods. On the basis of the 2 enzyme systems, Shikimate dehydrogenase (SKDH) and NADH dehydrogenase (NDH), the 2 larch species could be unequivocally distinguished in this case and therefore the proportion of hybrids and selfings (individual and clonal) exactly determined. The genetic control of these enzyme systems was analyzed by means of offspring of controlled (including reciprocal) crossings between one European and one Japanese larch. Five samples of different crop years of the hybrid seeds were examined. The proportion of full seeds ranged from $22-60 \%$ and the proportion of hybrids in full seed from 68.6$84.6 \%$, thus showing that this method of producing hybrids is very efficient. A further advantage of the use of 2 enzyme systems is the easier detection of minimum amounts of contamination, which in this case ranged from $1.0-6.7 \%$. The possible influence of the parental genotypes on the genetic structure of hybrids and possible explanations for the origin of the contamination are discussed.
\end{abstract}

\section{larch / hybrid / seed orchard / contamination}

Résumé - Taux d'hybridation dans la descendance d'un verger à graines composé de deux espèces de mélèze (Larix europaea et $L$ leptolepis). Le taux d'hybridation dans les lots de graines produits dans un verger contenant un clone de mélèze d'Europe (Larix europaea) utilisé comme arbre mère et 271 clones de mélèzes du Japon utilisés comme pollinisateurs a été déterminé par voie isoenzymatique. A l'aide de 2 systèmes isoenzymatiques : shikimate déshydrogénase (SKDH) et NADH déshydrogénase (NDH), on a été capable de distinguer clairement les 2 espéces et ainsi de déterminer exactement la fréquence d'hybrides et d'autofécondations. Le contrôle génétique de ces systèmes d'enzymes a été analysé à l'aide des descendants de croisements contrólés (y compris les réciproques) entre un mélèze d'Europe et un mélèze du Japon. Cinq échantillons de graines hybrides récoltés différentes années ont été examinés. Le taux de graines pleines s'élève de $22 \%$ à $60 \%$ et la proportion d'hybrides dans les graines pleines de $68,6 \%$ à $84,6 \%$, montrant ainsi que cette méthode de production de graines hybrides est très efficace. L'utilisation de 2 systèmes d'enzymes facilite, en outre, la détection de quantités minimes de contamination $(1,0-6,7 \%)$ dans notre cas. L'influence exercée éventuellement par les génotypes parentaux sur la structure génétique des hybrides, et des hypothèses sur l'origine de cette pollution pollinique sont discutées. 


\section{INTRODUCTION}

Forest tree breeding is principally concerned with the improvement of growth, wood quality and vitality in tree species of economic interest. In order to realize such breeding aims as rapidly as possible, eg in one generation, the artificial generation of hybrids between 2 compatible species is performed, because possible combinations of desirable traits of both species are expected in their progeny. Our example of such interspecific hybrids, which have already shown hybrid vigour for many trait combinations, is Larix $\mathrm{x}$ eurolepis (Dengler, 1941; Hering et al, 1989), resulting from crosses between European larch ( $\mathrm{La}$ rix decidua Miller or L europaea DC) and Japanese larch (Larix kaempferi Sargent or $L$ leptolepis Gord) (for review and literature compilation, see Langner, 1952, 1971; Kleinschmit, 1988; Paques, 1989).

The hybrid seed collection designated LOLA 1 (Larix $x$ eurolepis) investigated in this study is the result of part of a breeding program with the aim of developing an inexpensive method for mass-producing hybrid seed material. For this purpose the seed production is based on windpollination of single European larch clones, which are selected according to their general combining ability with Japanese larch, by many Japanese larch clones: one grafted clone of European larch is planted in a Japanese larch stand or seed orchard; the European larch clone is used as maternal tree, the only tree from which seed is harvested, whereas the Japanese larch clones serve as pollen parents. The seed material collected from the European clone is therefore assumed to be a mixture of hybrids (outcrossed fullsibs or half-sibs) and selfings (individual and clonal). This method of producing hy- brid seed was expected to provide high proportions of hybrids (Stern, 1966).

Further aims of this breeding strategy are: 1) to obtain a certain uniformity and repeatability of different hybrid seed collections by using one European larch clone as maternal tree; and 2) to obtain the greatest possible genetic variability in the hybrid seed collections by using many Japanese larch clones as pollinators (in contrast to seed orchards with few - sometimes only 2 - clones). The results are genetically different hybrid seed collections, which are the basis for multisite experiments to study the stability of hybrid vigour over a range of environments, as suggested by Paques (1989). Since 1971 about 100 different hybrid seed collections have been tested in 30 field experiments distributed over Germany, Austria and France (Langner, in preparation).

But hybrid breeding programs based upon wind pollination make no sense, however, unless one can be sure that hybrids will actually be obtained. To our knowledge there exist only a few studies which have identified the proportion of hybrids (Adams and Coutinho, 1977; Joly and Adams, 1983; Bergmann and Ruetz, 1987), but some of these estimates are very uncertain. The determination of the proportion of hybrids should be possible by the use of isoenzyme gene markers similar to the method described by Bergmann and Ruetz (1987).

Since the maternal trees are one clone and thus always have the same genotype (in contrast to seed orchards where seed is collected from different clones), there was a good chance to detect isoenzyme markers with sufficient differences between the parent species to identify the hybrids. The determination of the proportion of hybrids was carried out in 4 steps. 


\section{Species distinction by enzyme systems}

Preliminary investigations of enzyme systems in order to detect suitable isoenzyme markers, ie enzymes of which European and Japanese larches have distinct isoenzyme variants/alleles. One possible enzyme system was already known: Shikimate dehydrogenase (SKDH). However, this system had only been tested in a 2clone seed orchard (Bergmann and Ruetz, 1987) and therefore would possible not suffice to identify hybrids in a seed orchard with 271 Japanese larch clones.

\section{Genetic analysis}

Analysis of the genetic control of the suitable enzymes on the basis of controlled (including reciprocal) crossings between one European and one Japanese larch.

\section{Consistency of genetic differences}

A test of whether the differences in isoenzyme variants between European and Japanese larch detected in the preliminary investigations (step 1) are valid for the one European and all Japanese larch clones used in the seed orchards.

\section{Proportion of hybrids}

Determination of the proportion of hybrids in different samples from LOLA 1 with the following questions in mind:

- are there differences between the single seed orchards in the proportion of hybrids, especially between one not sufficiently isolated seed orchard and the others?

- are there differences in the proportion of hybrids between different crop years?

\section{MATERIALS AND METHODS}

\section{Species distinction by enzyme systems}

Preliminary isoenzyme studies were carried out with a bulk seed lot from the Alps for the European larch and with a seed sample of a collection from the seed orchard Jagen 7 (described below) for the Japanese larch. In addition to SKDH (Shikimate dehydrogenase, E.C.1.1.1.25) which was found to be suitable here, NDH (NADH dehydrogenase, E.C.1.6.99.3) was found to be useful for the distinction of European and Japanese larch.

For isoenzyme analysis, the meristem tissue of dormant buds or the endosperm tissue of seeds which were soaked in water for 3-4 days was homogenized with a Tris-HCl buffer of $\mathrm{pH}$ 7.2 containing 1\% PVP. These homogenates were directly subjected to horizontal starch gel electrophoresis. SKDH and NDH isoenzymes were separated in a Tris-citric acid buffer system of $\mathrm{pH}$ 7.0. Following electrophoretic separation, the starch gel was sliced horizontally and each gel slab was stained for an enzyme system. The SKDH system was stained in a $0.1 \mathrm{M}$ Tris- $\mathrm{HCl}$ buffer $(\mathrm{pH} 8.0$ ) containing $1.5 \mathrm{mg} / \mathrm{ml}$ shikimic acid, $0.2 \mathrm{mg} / \mathrm{ml} \mathrm{MTT}, 0.2 \mathrm{mg} / \mathrm{ml}$ NADP and $0.05 \mathrm{mg} / \mathrm{ml}$ PMS; the NDH system was stained in a $0.1 \mathrm{M}$ Tris-HCl buffer $(\mathrm{pH} 7.0)$ containing $0.3 \mathrm{mg} / \mathrm{ml} \mathrm{NADH}$ and $0.2 \mathrm{mg} / \mathrm{ml} \mathrm{MTT}$.

\section{Genetic analysis}

The genetic control of the isoenzyme variants of the 2 enzyme systems was tested with seeds from heterozygous hybrids. To be sure that the assayed trees were hybrids, seeds were collected in December 1989 from the progenies of both reciprocal crossings between one European and one Japanese larch (Langner, 1952). About 100 endosperms (macrogametophytes) of each progeny were assayed to test for the expected 1: 1 segregation of the 2 alleles in their haploid state (Feret and Bergmann, 1976).

\section{Consistency in genetic differences}

For genotyping the various Japanese larch clones and the one European clone Feh 17, dor- 
mant buds from all Japanese larch clones used a pollinators and from Feh 17 were collected in October, 1989.

\section{Proportion of hybrids}

The hybrid seed collection LOLA 1 is produced in 3 seed orchards at Klausheide near Lingen in the northwest of Germany. The largest (1.67 ha) orchard, named Küchengarten, was established in 1962 as a Japanese larch conservation orchard with 261 clones, each with 4 grafted ramets, planted in a line with a distance of $4 \times 4 \mathrm{~m}$ between trees. These clones originated from 32 indigenous larch stands in Japan. After loss of many ramets because of frost, in 1971 grafted ramets of one clone of European larch (Feh 17) were planted in the vacant positions, thus assumed to be randomly distributed. The European larch Feh 17 is a tree of unknown origin, which showed in crossing experiments of Langner (personal communication) a good general combining ability with Japanese larches. In October 1989, this seed orchard contained 193 Japanese larch clones with 1 to 4 ramets each and 487 ramets of the Feh 17 clone.

The second seed orchard, named Jagen 7 (0.8 ha), was similarly established in 1962 and originally contained 110 clones of Japanese larch (other than in Küchengarten), each with 4 grafted ramets a line. Grafted ramets of the Feh 17 clone were planted in 1971 in every other diagonal row. In 1987, there were still 79 clones and 150 ramets of the Feh 17 clone. For extension of approval regarding LOLA 1 according to the German legislation concerning forest reproductive material it was required that the proportion of hybrids in its seed crop be examined be- cause this seed orchard was not sufficiently isolated from other larches in the neighbourhood.

The third seed orchard, named Jagen $10(0.6$ ha), was originally a Japanese larch stand with offspring from several clones of the first seed orchard before grafted ramets of Feh 17 were planted in 1971 in every other diagonal row.

The top of all ramets of the Feh 17 clone was pruned to a height of $6 \mathrm{~cm}$. Stocks taking over grafted scions were not observed.

To estimate the proportion of hybrids in the seed crop, the embryos in 5 samples of LOLA 1 were examined: Jagen 7 1987, LOLA 1 (all three seed orchards combined) 1984, Küchengarten 1986, 1987 and 1989. A seed sample of Küchengarten from 1983 could not be examined because of a very low proportion of full seed ( $\leq$ $1 \%)$.

\section{RESULTS}

\section{Species distinction by enzyme systems}

The banding patterns of the 2 enzymes (SKDH and NDH) in the 2 species are shown in figure 1. Both enzymes show only 1 zone of activity in zymograms. Altogether NDH showed 2 and SKDH 3 isoenzyme variants differing in mobility. All assayed Japanese larches showed only the fastest migrating isoenzyme variants $\left(\mathrm{NDH}-\mathrm{A}_{2}, \mathrm{SKDH}-\mathrm{A}_{3}\right)$. The bulk seed lot of European larch showed all detected isoenzyme variants with frequencies $\geq 20 \%$.

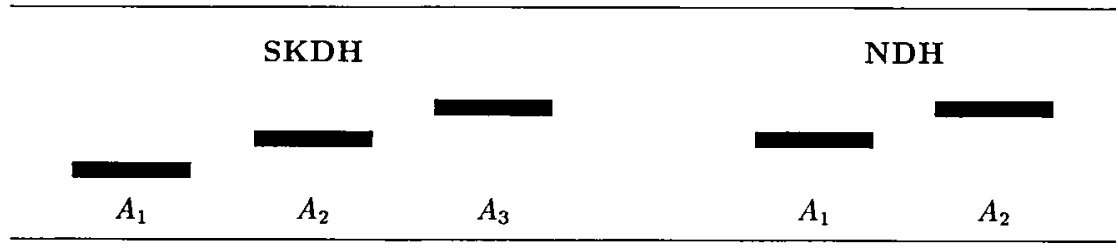

Fig 1. Banding patterns of SKDH and NDH in the endosperms (macrogametophyte) of European and Japanese larch seed. For SKDH only the $A_{3}$-allele and for NDH only the $A_{2}$-allele occurred in Japanese larch, in European larch occurred all observed alleles. Feh 17 possesses SKDH- $A_{2}$ and NDH$A_{1}$. 
The banding patterns were consistent in different tissues. Endosperm, embryo and buds of one tree showed consistent patterns but with differing intensity. Embryos had the weakest, buds the strongest staining intensity.

\section{Genetic analysis}

The results obtained from the examination of the endosperms in seeds from the progenies of controlled crossings are given in table $I$ and show no significant deviation from the expected values. This supports the hypothesis that the variable activity zones of each enzyme system are controlled by a single gene locus. The banding patterns are therefore ascribed to alleles at a gene locus and are designated as SKDH-A $, A_{2}, A_{3}$ and NDH-A,$A_{2}$.

\section{Consistency in genetic differences}

The European larch clone Feh 17 has the genotype SKDH-A $A_{2}, N D H-A_{1} A_{1}$. All 271 Japanese larch clones used in the seed or- chards as pollinators have the genotype SKDH- $A_{3} A_{3}, N D H-A_{2} A_{2}$, thus unequivocally distinguishable from Feh 17 by these enzymes. In figure 2 are shown, for example, the banding patterns of Feh 17 among some Japanese larch clones.

An additional test of the applicability of the 2 enzymes for determining hybrid larches was done with unknown crossing material, which was kindly supplied by $W$ Ruetz (Bayerische Landesanstalt für forstliche Saat- und Pflanzenzucht, Teisendorf). Nine trees obtained by controlled crossings were identified. The respective zymograms are shown in figure 3. Tree $D$ was regarded as Japanese larch, trees $A$, $B, E, F, G$ as hybrids between Japanese and European larch. This result was correct (Ruetz, personal communication). Trees $\mathrm{C}, \mathrm{H}$ and $\mathrm{J}$ could not be exactly identified on the basis of the above results. Tree $\mathrm{C}$ and $\mathrm{J}$ were assumed to be hybrids with Japanese larch as one parent tree, but the origin of the faster migrating band than that of the Japanese larch could not be ascertained. For tree $\mathrm{H}$ it could only be said that one parent tree must be a European larch, and the origin of the intermedi-

Table I. Segregation ratios of seed endosperm from 2 maternal trees which represent offspring of 2 reciprocal crossings between 1 Japanese (No 5) and one European (No 6) larch. Tree No 460 results from crossing $5 \times 6$, tree 428 from crossing $6 \times 5$. Critical limit of $\chi^{2}$ for the $\chi^{2}$-test with level of significance 0.05 is $\mathrm{K}=3.841$.

\begin{tabular}{llllllll}
\hline $\begin{array}{l}\text { Enzyme } \\
\text { system }\end{array}$ & Tree No & $N$ & Expectation & Observed Frequency & $\chi^{2}$ \\
\hline SKDH & $\mathrm{A}_{2} \mathrm{~A}_{3}$ & & $\mathrm{~A}_{2}$ & $\mathrm{~A}_{3}$ & $\mathrm{~A}_{2}$ & $\mathrm{~A}_{3}$ & \\
& 460 & 102 & 51 & 51 & 41 & 60 & 3.17 \\
& 428 & 95 & 47.5 & 47.5 & 49 & 46 & 0.09 \\
$\mathrm{NDH}$ & $\mathrm{A}_{1} \mathrm{~A}_{2}$ & & $\mathrm{~A}_{1}$ & $\mathrm{~A}_{2}$ & $\mathrm{~A}_{1}$ & $\mathrm{~A}_{2}$ & \\
& 460 & 104 & 52 & 52 & 53 & 51 & 0.04 \\
& 428 & 95 & 47.5 & 47.5 & 57 & 38 & 3.80 \\
\hline
\end{tabular}




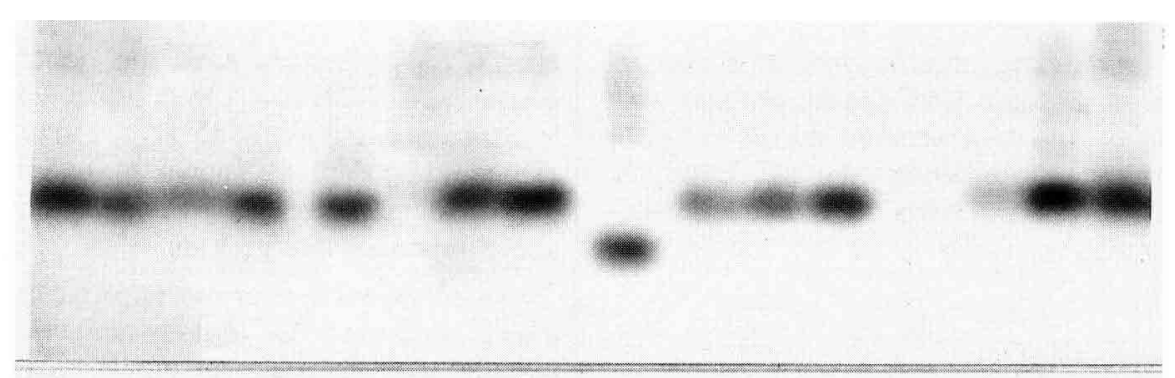

Fig 2. Zymograms of the European larch clone Feh 17 (deviant pattern near the middle) among some of the Japanese larch clones. Above SKDH, below NDH. Assayed tissue: dormant buds.

ate band could not be ascertained. The solution was (Ruetz, personal communication) tree $C$ being a Siberian larch (Larix sibirica), tree $\mathrm{J}$ a back-cross between a hybrid (between European and Japanese larch) and a Siberian larch and tree $\mathrm{H}$ an European larch (with an additional allele in this case). These results demonstrate the reliability of this method of identifying hybrids.

\section{Proportion of hybrids}

The examination of the different seed samples of LOLA 1 revealed the following em- bryo genotypes (see fig 4): at each locus heterozygotes (SKDH-A $\left.A_{3}, N D H-A_{1} A_{2}\right)$ were regarded as hybrids. At each locus homozygotes (SKDH- $A_{2} A_{2}, N D H-A_{1} A_{1}$ ) for the alleles of the Feh 17 clone were regarded as selfed seed of this clone. In addition 2 unexpected genotypes occurred: at one locus homozygous for the allele of the Feh 17 clone and heterozygous at the other locus (SKDH-A $A_{2}, N D H-A_{1} A_{2}$ and SKDH $A_{2} A_{3}, N D H-A_{1} A_{1}$, respectively). These last 2 genotypes must stem from contamination from other pollen sources, because they cannot result from the clones in the seed orchards (for possible explanations, see Discussion).

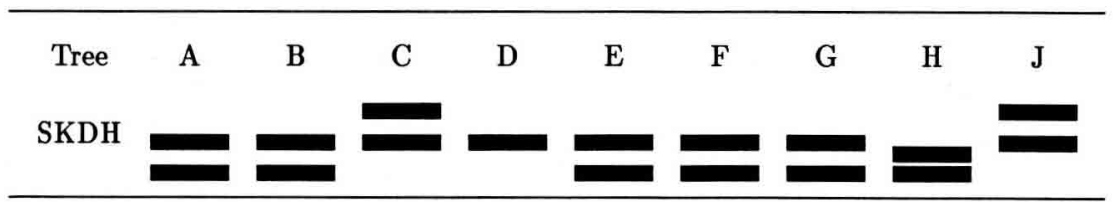

Fig 3. Banding patterns of unknown crossing material. The patterns of $\mathrm{NDH}$ are similar. Trees $\mathrm{A}, \mathrm{B}$, $E, F, G$ could be identified as hybrids between Japanese and European larch and tree $D$ as Japanese larch. Trees $\mathrm{C}, \mathrm{H}, \mathrm{J}$ could not be exactly identified (see text). 


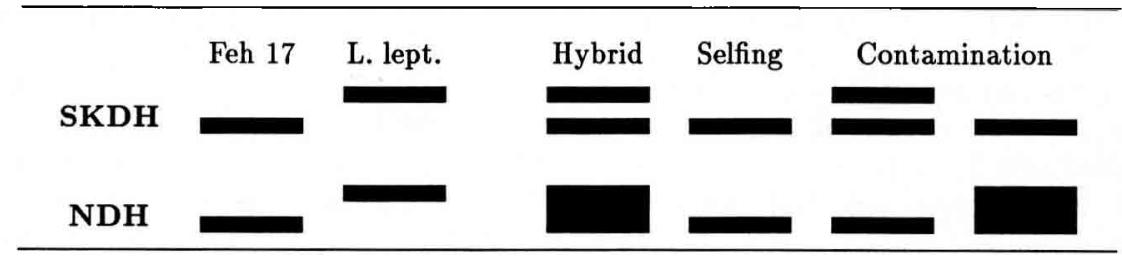

Fig 4. Isoenzyme phenotypes of parental trees (left) and observed in the LOLA 1 seed collection (right).

The proportions of the 4 genotypes in the examined samples are given in table II. The proportion of hybrids ranged from $68.6-84.6 \%$, selfings from $9.6-30.4 \%$, contamination from $1.0-6.7 \%$.

The proportion of full seeds was very variable and ranged approximately from $\leq$ $1 \%$ (Küchengarten, 1983; therefore not examined) to $60 \%$ (LOLA 1 1984). It was not determined in every sample exactly, so that we must partially rely on the declarations of the producer (see table II).

\section{DISCUSSION}

Due to the results of the preliminary studies and the investigations of the 271 Japanese larch clones, it can be assumed that the Japanese larch is fixed at both loci: at $\mathrm{NDH}$ for the $\mathrm{A}_{2}$-allele and at SKDH for the $A_{3}$-allele. In the bulk seed lot of European larch one additional allele $\left(A_{1}\right)$ occurred at the NDH locus and 2 additional alleles $\left(A_{1}\right.$, $A_{2}$ ) at the SKDH locus. This may be evidence favouring the assumption that the

Table II. Numbers and percentages of the 4 genotypes indifferent samples of LOLA 1.

\begin{tabular}{|c|c|c|c|c|c|c|c|c|c|c|}
\hline \multirow[t]{3}{*}{ Seed collection } & \multirow{3}{*}{$\begin{array}{l}\% \\
\text { Full } \\
\text { seed }\end{array}$} & \multicolumn{8}{|c|}{$\begin{array}{c}\text { Genotypes } S K D H \\
N D H\end{array}$} & \multirow[b]{3}{*}{$\Sigma$} \\
\hline & & \multirow{2}{*}{\multicolumn{2}{|c|}{$\begin{array}{l}\text { Hybrids } \\
A_{2} A_{3} \\
A_{1} A_{2} \%\end{array}$}} & \multirow{2}{*}{\multicolumn{2}{|c|}{$\begin{array}{c}\text { Selfing } \\
A_{2} A_{2} \\
A_{1} A_{1} \\
N^{2} \%\end{array}$}} & \multicolumn{4}{|c|}{ Contamination } & \\
\hline & & & & & & $\begin{array}{c}A \\
A \\
N\end{array}$ & $\begin{array}{c}a_{3} \\
a_{1} \\
\%\end{array}$ & $\stackrel{A}{A}$ & $A_{2}$ & \\
\hline $\begin{array}{l}\text { Jagen } 7 \\
\text { LOLA } 1\end{array}$ & $\begin{array}{l}45 \\
60\end{array}$ & $\begin{array}{l}69 \\
70\end{array}$ & $\begin{array}{l}71.9 \\
68.6\end{array}$ & $\begin{array}{l}21 \\
31\end{array}$ & $\begin{array}{l}21.9 \\
30.4\end{array}$ & $\begin{array}{l}5 \\
0\end{array}$ & 5.2 & $\begin{array}{l}1 \\
1\end{array}$ & $\begin{array}{l}1.0 \\
1.0\end{array}$ & $\begin{array}{r}96 \\
102\end{array}$ \\
\hline $\begin{array}{r}1986 \\
1987 \\
1989\end{array}$ & $\begin{array}{l}22^{*} \\
750^{*} \\
925\end{array}$ & $\begin{array}{l}88 \\
83 \\
85\end{array}$ & $\begin{array}{l}84.6 \\
83.8 \\
81.7\end{array}$ & $\begin{array}{l}13 \\
15 \\
10\end{array}$ & $\begin{array}{r}12.5 \\
15.2 \\
9.6\end{array}$ & $\begin{array}{l}2 \\
1 \\
0\end{array}$ & $\begin{array}{l}1.9 \\
1.0\end{array}$ & $\begin{array}{l}1 \\
0 \\
7\end{array}$ & 1.0 & $\begin{array}{r}104 \\
99 \\
104\end{array}$ \\
\hline
\end{tabular}

- Declaration of producer. 
European larch species is genetically more differentiated than the Japanese larch, which is supported by the results of several provenance trials (Kramer, 1988, $p$ 153). Because the clone Feh 17 has other alleles at both loci than the Japanese clones, it can be expected that the heterozygosity of the hybrids increases at both loci from $0 \%$ within the parental trees to $100 \%$ within the hybrids. The amount of this increase depends primarily on the genotype of the European larch used as maternal tree, because this is the more variable species. Furthermore, the genotype of the maternal tree determines the number of possible genotypes within the hybrids according to the presence or absence of common alleles with the Japanese larch. The resulting possibilities for the increase in heterozygosity, allelic and genotypic structure and their combination are shown exemplarily by the 2 loci controlling SKDH and NDH: if the European larch is homozygous in both enzyme systems for the same allele that the Japanese larches have, no increase in heterozygosity results, the hybrids being uniformally homozygous at both loci. If the European larch is heterozygous with one common allele at both loci, the increase of heterozygotes will amount to $50 \%$ at each locus with 4 possible genotypes within the hybrids (25\% homozygous at one and homozygous at the other locus). In this case the allelic polymorphism corresponds to a genotypic polymorphism. If the European larch is homozygous at both loci for an allele other than the Japanese larch, the resulting hybrids are uniformally heterozygous. Here we have an allelic polymorphism connected with a genotypic monomorphism, as is the case in LOLA 1. Without regarding possible intermediate combinations, the most variable combination is the European larch being heterozygous with no common allele at either locus. Heterozygosity would increase from $0 \%$ within the parental trees to $100 \%$ within the hybrids at both loci, but there would be 4 possible genotypes within the hybrids: $25 \%$ of each combination of the 2 possible heterozygous genotypes at each locus. These considerations may demonstrate that the genetic structures of different hybrid seed collections and their response to different environments are expected to vary greatly. Further investigations will reveal possible relations between genetic structure and growth habit on different test sites.

The proportion of hybrids on LOLA 1 is relatively high compared to other results (cf Joly and Adams, 1983; Bergmann and Ruetz, 1987), and there are no considerable differences among the different seed orchards or crop years. It is a somewhat surprising result that, regardless of the proportion of full seeds, the proportion of hybrids is relatively high and varies only

Table III. Proportions of hybrids, selfings and contamination detected with each enzyme system compared to the application of both systems simultaneously in a seed sample of Jagen 71987.

\begin{tabular}{llllllll} 
Enzyme system & $N$ & \multicolumn{2}{c}{ Hybrids } & \multicolumn{2}{c}{ Selfings } & \multicolumn{2}{c}{ Contamination } \\
\hline SKDH & 96 & 74 & $77.1 \%$ & 22 & $22.9 \%$ & - & - \\
NDH & 96 & 70 & $72.9 \%$ & 26 & $27.1 \%$ & - & - \\
SKDH + NDH & 96 & 69 & $71.9 \%$ & 21 & $21.9 \%$ & 6 & $6.2 \%$ \\
& & & & & & &
\end{tabular}


slightly. For example, it is conceivable that, because of weather conditions, the European larch flowers before or after the Japanese larches, thus yielding a low percentage of full seeds which are only being selfings. Dieckert (1964) observed a decrease in the proportion of full seeds after controlled selfing of European larches. In the LOLA 1 plantations there must be at least a partial overlap of the flowering times. It can be assumed that the overlapping flowering time is different from year to year, resulting in a different amount of selfpollination of the European larch clone Feh 17 in the non-overlapping time. According to the above-mentioned observation of Dieckert (1964), the different amounts of self-pollination are possibly expressed in the different proportions of empty seeds in the LOLA 1 seed lots. Nevertheless, the hybrids may differ from year to year with regard to the male contribution of the Japanese larch clones. In any case it is an important statement that the proportion of hybrids is very high in all years sampled. Obviously, this method of producing hybrid seed is very efficient.

An advantage of the application of more than one enzyme system to estimate the proportion of hybrids lies in the easier detection of contamination. With one system this is only possible if a third allele occurs in the foreign pollen (as was the case in the unknown sample). The application of only 1 system would result in an overestimation of the proportions of hybrids and selfings, the amount depending on the applied enzyme. Table III shows the proportions of types in the 4 samples esimated with each enzyme system and the resulting overestimation compared to the results obtained with 2 enzyme systems. The amount of overestimation obviously depends on the proportion of contamination.

However, the application of 2 enzyme systems simultaneously still overestimates the proportion of hybrids and selfings, because the contaminating pollen may well contain the "correct" alleles. Based upon the results of the presented investigations, there exist two possibilities to explain the observed contamination: 1) Pollen of European larches containing other than the Feh 17-alleles contaminate; 2) pollen of hybrids heterozygous at both loci contaminate. In this case, the contamination would be twice as high as that estimated by the 2 phenotypes regarded as contamination. These 2 phenotypes result from only 2 of the 4 possible recombinants, which would be equal in frequency. The other 2 recombinants would yield the hybrid and the selfing phenotype, respectively.

The highest percentages of contamination are in the seed samples of Jagen 7 1987 (6.2\%) and Küchengarten 1989 $(6.7 \%)$. The larches close to Jagen 7 are Japanese larches grown from seed produced in Germany. For that reason the most probable explanation for the contamination in the seed of Jagen 7 is the second of the above noted possibilities, because in Japanese larch seed produced in Germany hybrids are most likely to occur, and it is very improbable that these Japanese larches possess other alleles than all 271 examined clones sampled over the whole distribution range of Japanese larch. The neighbour trees of Jagen 7 could not be analysed because of their immense number. The contamination in the seed sample of Küchengarten 1989 can not be explained as pollen contamination, because no other larches are adjacent to this orchard. It is conspicuous that the contamination in a non-negligible amount occurs only in one year. Probably this is seed contamination during seed extraction, as is assumed for the other negligible amounts of contamination amounting $\approx 1 \%$. Considering the high proportions of hybrids in the LOLA 1 seed, pollen contamination is not a 
serious problem, because the maternal tree is selected on the basis of a good general combining ability and the breeding method has the aim of obtaining the greatest possible genetic variability by way of the pollen parents.

\section{ACKNOWLEDGMENTS}

The authors are greatly indebted to $\mathrm{W}$ Langner for motivating and introducing them to the project and to $S$ Roestel from the $F$ von LochowPetkus $\mathrm{GmbH}$, whose instrumental support made this project possible. HR Gregorius and $\mathrm{HH}$ Hattemer are thanked for helpful criticism and discussion, E Gillet Gregorius for carefully reading the manuscript, $R$ Finkeldey and an anonymous reviewer for indicating several shortcomings and G Husmann for collecting the seed samples. This work was financially supported by the $F$ von Lochow-Petkus $\mathrm{GmbH}$ and the BMFT.

\section{REFERENCES}

Adams WT, Coutinho S (1977) Isoenzyme genetic markers useiul for studies of the Pinus rigida $\times$ Pinus taeda hybrid. In: Proc 24th Northeastern Forest Tree Impr Conf, 1-13

Bergmann F, Ruetz W (1987) Identifizierung von Hybridlärchensaatgut aus Samenplantagen mit Hilfe eines Isoenzym-Markers. Silvae Genet 36, 102-104

Dengler A (1941) Bericht über Kreuzungsversuche zwischen Trauben- und Stieleiche
(Quercus sessiliflora Smith $\times$ Quercus pedunculata Ehrh bzw robur $L$ ) und zwischen europäischer und japanischer Lärche (Larix europaea bzw decidua $x$ Larix leptolepis Murray bzw kaempferi Sargent). Mitt Akad Dtsch Forstwiss 1, 87-109

Dieckert $H$ (1964) Einige Untersuchungen zur Selbststerilität und Inzucht bei Fichte und Lärche. Silvae Genet 13, 77-84

Feret PP, Bergmann F (1976) Gel electrophoresis of proteins and enzymes. In: Modern Methods in Forest Genetics (Miksche JP, ed) Springer-Verlag Berlin, Heidelberg, 49-77

Hering S, Haasemann W, Braun H (1989) Ergebnisse eines 19 jährigen Anbauversuchs mit Hybrid-, Europäer- une Japanerlärchen im Rauchschadgebiet des oberen Erzgebirges. Beitr Forstw 23, 11-17

Joly RJ, Adams WT (1983) Allozyme analysis of pitch $x$ loblolly pine hybrids produced by supplemental mass-pollination. For Sci 29, 423432

Kleinschmit $J(1988)$ Konsequenzen aus den Lärchen-Herkunftsversuchen für die LärchenZüchtung. Forstu Holz 11, 259-262

Kramer H (1988) Waldwachstumslehre. Parey, Hamburg

Langner W (1952) Kreuzungsversuche mit Larix europaea DC und Larix leptolepis Gord. $Z$ Forstgen 1, 2-21, 40-56

Langner W (1971) 33 Jahre Hybridlärchenzüchtung. $A F Z 26,54-55$

Paques LE (1989) A critical review of larch hybridization and its incidence on breeding strategies. Ann Sci For 46, 141-153

Stern K (1966) Anerkennung von Hybridplantagne oder von Hybridpflanzen. Forstpfl Forstsamen 3, 37-40 